\title{
A Conjugative Plasmid Carrying the efe Gene for the Ethylene-Forming Enzyme Isolated from Pseudomonas syringae pv. glycinea
}

\author{
K. Watanabe, K. Nagahama, and M. Sato
}

First and third authors: National Institute of Sericultural and Entomological Science, Tsukuba, Ibaraki 305-8634, Japan; and second author: Kumamoto Institute of Technology, Ikeda, Kumamoto 860-0082, Japan.

Accepted for publication 9 August 1998.

\begin{abstract}
Watanabe, K., Nagahama, K., and Sato, M. 1998. A conjugative plasmid carrying the efe gene for the ethylene-forming enzyme of Pseudomonas syringae pv. glycinea Phytopathology 88:1205-1209.

Previous work suggested that the efe gene encoding the ethylene-forming enzyme was present in the plasmids of three pathovars of Pseudomonas syringae including glycinea, phaseolicola (kudzu strains), and cannabina. However, no direct evidence to support this assumption had been presented. In the current study, we isolated the conjugative plasmid harboring the efe gene (ethylene plasmid) designated $\mathrm{pETH} 2$ from $P$. syringae pv. glycinea MAFF301683. pETH2 was detected by Southern blot hybridization using the efe probe, marked with the transposon mini-
\end{abstract}

ABSTRACT

Tn5-Km1, and transferred into $P$. syringae $\mathrm{Ni27}$, which does not produce ethylene. The transconjugant $\mathrm{Ni} 27^{\mathrm{n}}$ (pETH2) produced ethylene at a level similar to pv. glycinea MAFF301683. In addition, the plasmid designated pCOR2, which encodes coronatine biosynthesis genes, was detected in the same strain. Although the molecular size of the plasmid pCOR2 was not easily distinguishable from $\mathrm{pETH} 2$, pCOR2 transferred independently into $\mathrm{Ni} 27^{\mathrm{n}}$ and the transconjugants produced coronatine. These findings suggested that the efe gene has been horizontally dispersed among pathovars of $P$. syringae by plasmid-mediated conjugation in nature.

Additional keywords: gene transfer, plant hormone, polymerase chain reaction.

Ethylene is a plant hormone involved in the regulation of numerous physiological processes that may play some role in pathogenicity. Ethylene is also produced by microorganisms including a limited number of plant-pathogenic bacteria $(4,7,20,21,24)$. Four pathovars of Pseudomonas syringae including phaseolicola (kudzu strain), glycinea, cannabina, and sesami produce ethylene very efficiently through a biochemical pathway using 2-oxoglutarate, which is controlled by the gene efe $(7,20,21,24)$. These findings suggested that efe had been horizontally dispersed among pathovars of $P$. syringae through conjugation, natural transformation, or transduction.

Conjugation may play a major role in the dispersion of efe. Nagahama et al. (11) reported that efe may be encoded in indigenous plasmids in the pathovars phaseolicola and glycinea by Southern blot analysis using an efe gene probe. Sato et al. (21) showed that plasmids in all the strains of the pathovars glycinea and phaseolicola hybridized with the efe probe. Furthermore, Sato et al. (21) also obtained data using Southern blot analysis and polymerase chain reaction (PCR) detection of efe in the plasmid indicating that pv. cannabina MAFF302256 may harbor an ethylene plasmid. However, no direct evidence for the plasmid location of efe of $P$. syringae has been obtained, since the assumption was based only on analyses by Southern blot hybridization and PCR.

On the other hand, it remained to be determined whether the ethylene-producing phenotype of these pathovars is advantageous for survival on their host Leguminosae plants (pathovars phaseolicola, glycinea, and cannabina) and Sesamum indicum (pv. sesami). A previous study suggested that ethylene production in planta may play an important role in the pathogenicity of $P$. syringae pv. glycinea (24). The purpose of this study was to produce ethylene-

Corresponding author: K. Watanabe; E-mail address: nabek@nises.affrc.go.jp

Publication no. P-1998-0922-01R

(C) 1998 The American Phytopathological Society producing strains by transferring the ethylene plasmid into nonproducing strains; these strains could be used for analyses of the role of efe in the pathogenicity or survival of $P$. syringae.

In the current study, we obtained direct evidence that a plasmid of $P$. syringae pv. glycinea MAFF301683 carries the efe gene and is self-transmissible.

\section{MATERIALS AND METHODS}

Bacterial strains and plasmids. The bacterial strains used in this study are listed in Table 1 . The plasmid pKEFE (5.6 kb), harboring efe of pv. phaseolicola strain PK2, was used as a DNA probe for Southern blot hybridization. To estimate the molecular size of the indigenous plasmids, the following plasmid molecular size standards were used: three indigenous plasmids of $P$. syringae pv. mori S6801 (91, 76, and $38 \mathrm{~kb})(18)$ and two plasmids from $P$. syringae pv. tabaci BR2 (RSF1010) (19), which harbors the indigenous plasmid pBPW1 (45 kb) and the Escherichia coli Rplasmid RSF1010 (8.9 kb).

The molecular size was measured by Kodak Digital Science 1D-2.02 software (Eastman Kodak Co., Rochester, NY).

Growth of bacteria. For the PCR assay and plasmid isolation, bacteria were grown on modified Luria-Bertani (LB) agar medium (10 $\mathrm{g}$ of peptone, $5 \mathrm{~g}$ of yeast extract, $10 \mathrm{~g}$ of $\mathrm{NaCl}$, and $15 \mathrm{~g}$ of agar per 1 liter of distilled water; tryptone in the original LB was replaced by peptone) or in modified LB broth overnight at $25^{\circ} \mathrm{C}$, respectively. To detect ethylene production, the bacteria were grown in modified LB medium with shaking.

Plasmid DNA isolation. Plasmid DNA was extracted according to the method of Birnboim and Doly (3) and separated by electrophoresis in Tris-borate buffer $(0.89 \mathrm{M}$ Tris-borate and $0.089 \mathrm{M}$ boric acid, $\mathrm{pH} 8$ ) at $8 \mathrm{~V} / \mathrm{cm}$ in $0.6 \%$ agarose for $3 \mathrm{~h}$.

Transposon mutagenesis. To obtain transposon-induced mutants, matings were performed on membranes (Nihon Millipore Ltd., Tokyo) overnight at $25^{\circ} \mathrm{C}$. E. coli S17 ( $\lambda$ pir) harboring 
pUT::mini-Tn5-Km1 (8) was used as the donor strain, and strain 301683-r, which was obtained spontaneously as a rifampicinresistant mutant of MAFF301683 in this study, was used as the recipient strain. An equal ratio of donor/recipient cells was used. To select transconjugants, modified LB medium containing $20 \mu \mathrm{g}$ of rifampicin per $\mathrm{ml}$ and $20 \mu \mathrm{g}$ of kanamycin per $\mathrm{ml}$ was used.

PCR analysis. To amplify the entire $e f e$ gene $(1.05 \mathrm{~kb})$, a pair of primers (21), ETH-1 (5'-ATGACCAACCTACAGACT-3') and ETH-2 (5'-TCATGAGCCTGTCGCGCG-3'), were designed from sequence data reported by Fukuda et al. (5). To amplify the $c f l$ region (one of the coronatine biosynthesis genes), a pair of primers (26), Cor1 (5'-GGCGCTCCCTCGCACTT-3') and Cor2 (5'GGTATTGGCGGGGGTGC-3'), were constructed from sequence

TABLE 1. Bacterial strains and plasmids

\begin{tabular}{|c|c|c|}
\hline Designation & Relevant properties $^{\mathrm{a}}$ & Source or reference \\
\hline $\begin{array}{l}\text { Strains } \\
\text { Pseudomonas syringae } \\
\text { pv. glycinea } \\
\text { MAFF301683 } \\
\text { MAFF302676 } \\
\text { MAFF302683 } \\
\text { MAFF302694 } \\
\text { MAFF302754 } \\
\text { 301683-r } \\
\text { 301683-r::mini-Tn5-P1 } \\
\text { 301683-r::mini-Tn5-P2 } \\
\text { 301683-r::mini-Tn5-P3 } \\
\text { 301683-r::mini-Tn5-P5 }\end{array}$ & $\begin{array}{l}\text { WT } \\
\text { WT } \\
\text { WT } \\
\text { WT } \\
\text { WT } \\
\text { RIF }^{\mathrm{r}} \\
\text { RIF }^{\mathrm{r}}, \mathrm{KM}^{\mathrm{r}} \\
\mathrm{RIF}^{\mathrm{r}}, \mathrm{KM}^{\mathrm{r}} \\
\mathrm{RIF}^{\mathrm{r}}, \mathrm{KM}^{\mathrm{r}} \\
\mathrm{RIF}^{\mathrm{r}}, \mathrm{KM}^{\mathrm{r}}\end{array}$ & $\begin{array}{l}\text { MAFF' } \\
\text { MAFF } \\
\text { MAFF } \\
\text { MAFF } \\
\text { MAFF } \\
\text { This study } \\
\text { This study } \\
\text { This study } \\
\text { This study } \\
\text { This study }\end{array}$ \\
\hline $\begin{array}{l}\text { pv. atropurpurea } \\
\text { NIAES } 1309\end{array}$ & WT & K. Nishiyama \\
\hline $\begin{array}{l}\text { pv. mori } \\
\text { S6801 } \\
\text { pv. tabaci } \\
\text { BR2 (RSF1010) } \\
\text { unknown pv. }\end{array}$ & $\begin{array}{l}\text { Plasmid size marker } \\
\text { Plasmid size marker }\end{array}$ & $\begin{array}{l}\text { M. Sato } \\
\text { Sato et al. (19) }\end{array}$ \\
\hline $\begin{array}{l}\mathrm{Ni27} \\
\text { Escherichia coli } \mathrm{S} 17(\lambda \text { pir }) \\
(\mathrm{pUT}: \text { :mini-Tn } 5-\mathrm{Km} 1)\end{array}$ & Transposon vector, $\mathrm{KM}^{\mathrm{r}}$ & Lorenzo et al. (7) \\
\hline $\begin{array}{l}\text { Plasmids } \\
\text { pTKB } \\
\text { pKEFE }\end{array}$ & $\begin{array}{l}\text { Mini-Tn } 5-\mathrm{Km} 1 \text { probe } \\
\text { efe Probe }\end{array}$ & $\begin{array}{l}\text { Watanabe et al. (23) } \\
\text { K. Nagahama }\end{array}$ \\
\hline
\end{tabular}

a $\mathrm{RIF}^{\mathrm{r}}, \mathrm{KM}^{\mathrm{r}}$, and NAL ${ }^{\mathrm{r}}$ : resistance to rifampicin $(20 \mu \mathrm{g} / \mathrm{ml})$, kanamycin $(20$ $\mu \mathrm{g} / \mathrm{ml})$, and nalidixic acid $(20 \mu \mathrm{g} / \mathrm{ml})$, respectively. WT $=$ wild type.

b MAFF: strains from the Ministry of Agriculture, Forestry and Fisheries, Japan.

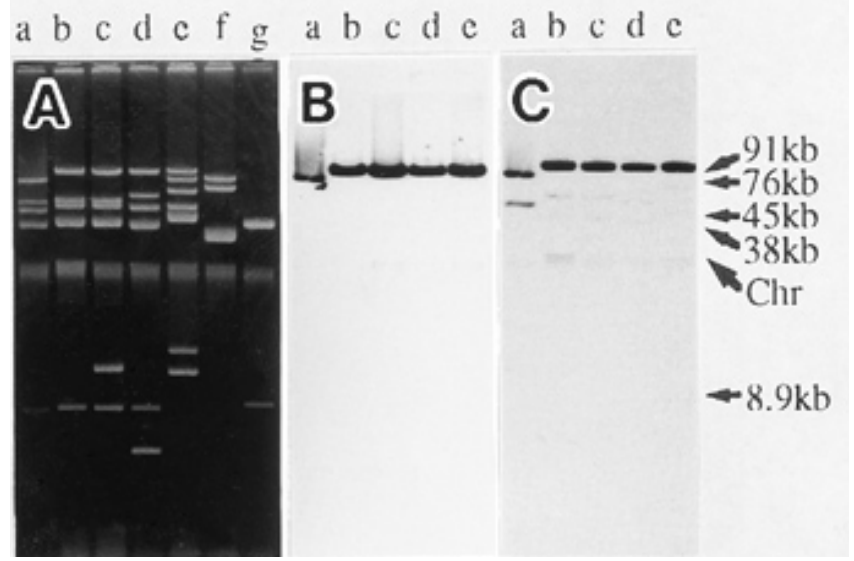

Fig. 1. Plasmid profiles of A, Pseudomonas syringae pv. glycinea strains and Southern blots of the plasmids probed with $\mathbf{B}$, the efe gene or $\mathbf{C}$, the $c f l$ gene. Lane a, pv. glycinea MAFF301683; b, MAFF302676; c, MAFF302683; d, MAFF302694; e, MAFF302754; f, pv. mori S6801; and g, pv. tabaci BR2 (RSF1010). Lanes f and g, molecular size markers (91-, 76-, and 38-kb plasmids of S6801, and 45- and 8.9-kb plasmids of BR2). Chr (arrow) shows the linear chromosomal DNA band. data reported by Bereswill et al. (2). Template DNAs were prepared by boiling a bacterial suspension $\left(10^{8} \mathrm{CFU} / \mathrm{ml}\right)$ for $5 \mathrm{~min}$. The standard reaction mixture $(50 \mu \mathrm{l})$ contained $1.5 \mathrm{mM} \mathrm{MgCl}$, $0.2 \mathrm{mM}$ of each dNTP, $1.25 \mathrm{U}$ of Taq DNA polymerase (Promega Corp., Madison, WI), 25 pmol of each primer, $5 \mu \mathrm{l}$ of $10 \times$ reaction buffer, and $2.5 \mu \mathrm{l}$ of boiled bacterial suspension. Amplification included 30 cycles of denaturation $\left(94^{\circ} \mathrm{C}\right.$ for $\left.1 \mathrm{~min}\right)$, annealing $\left(55^{\circ} \mathrm{C}\right.$ for $\left.2 \mathrm{~min}\right)$, and extension $\left(72^{\circ} \mathrm{C}\right.$ for $\left.3 \mathrm{~min}\right)$.

Southern blot analysis. Several probes were used in this study. To detect transposon insertions, a Tn5-Km1 ribo-probe (1.7-kb Bam HI fragment of mini-Tn5-Km1) was prepared from pTKB as described previously (23). To detect $c f l$, a $c f l$ probe was constructed from the PCR product of $P$. syringae pv. atropurpurea NIAES1309 obtained when the primer set Cor1-Cor2 (26) was used. To detect the $e f e$ region, an $e f e$ probe was constructed from the PCR product of pKEFE obtained when the primer set ETH1-ETH2 (21) was used. These probes were labeled with a digoxigenin DNA-labeling kit (Boehringer $\mathrm{GmbH}$, Mannheim, Germany) according to the manufacturer's protocol and used for Southern blot hybridization. Southern blot analysis was performed according to standard procedures (14) with some modifications (23).

Ethylene production. Ethylene production was measured by the method described by Nagahama et al. (11). To measure the rate of ethylene production by bacterial strains, the bacteria were inoculated into modified LB liquid medium $(200 \mathrm{ml})$ in a $500-\mathrm{ml}$ Erlenmeyer flask and incubated with slow rotary shaking (180 rpm) at $25^{\circ} \mathrm{C}$ overnight. A portion of each culture $(1 \mathrm{ml})$ was then transferred to a 34-ml test tube for the ethylene assay. The remainder of each culture was used for the measurement of the dry weight of bacteria after they were pelleted by centrifugation at $8,000 \times g$. The test tube for the ethylene assay was sealed with a rubber serum cap and incubated with slow rotary shaking $(180 \mathrm{rpm})$ at $25^{\circ} \mathrm{C}$ for $1 \mathrm{~h}$. A gas sample $(1 \mathrm{ml})$ was withdrawn through the rubber seal with a gas-tight syringe and analyzed with a Yanaco G3810 gas chromatograph (GC) (Yanaco Co., Kyoto, Japan) equipped with an activated alumina column and a hydrogen flame ionization detector. The rate of ethylene production was expressed as $\mathrm{nl}$ of ethylene ( $\mathrm{mg}$ of cell dry weight) $\mathrm{h}^{-1}$.

Coronatine assay. To detect the production of coronatine by bacterial strains, the potato assay previously described by Nishiyama (12) was used.

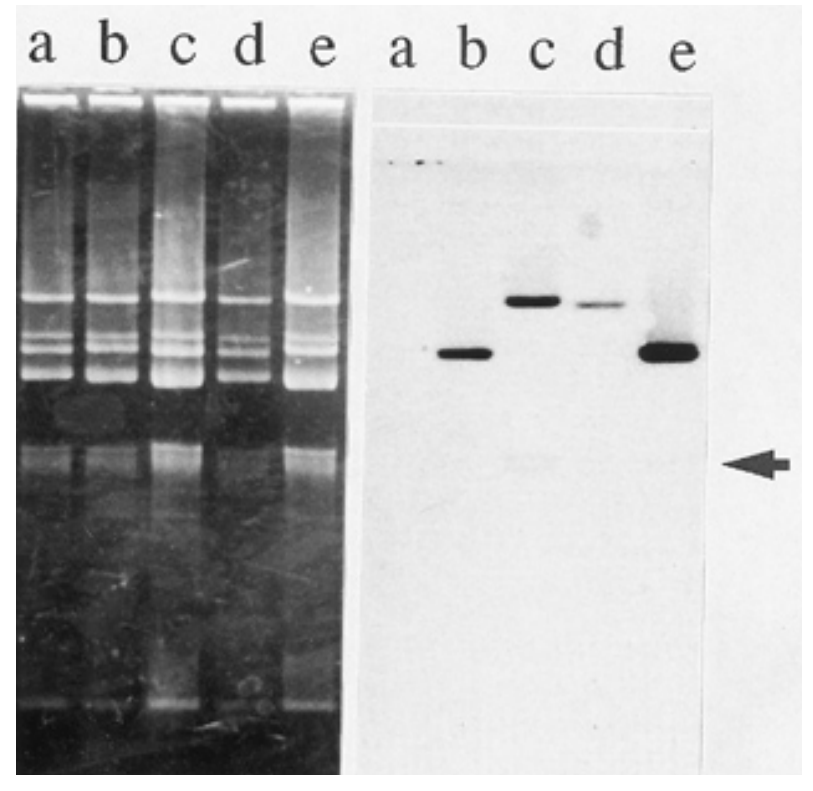

Fig. 2. Southern blot hybridization to the plasmids of MAFF301683::miniTn5-Km1 with the Tn5-Km1 ribo-probe. Lane a, MAFF301683 wild type; and b, c, d, and e, transconjugants with mini-Tn5-Km1 designated as P1, P2, P3, and P5, respectively. An arrow shows the linear chromosomal DNA band. 


\section{RESULTS}

Detection of plasmids. Five strains of pv. glycinea (MAFF301683, MAFF302676, MAFF302683, MAFF302694, and MAFF302754) were examined for their plasmid content. All of the strains harbored several plasmids as follows: MAFF301683 $(93,68,59$, and $47 \mathrm{~kb})$, MAFF302676 (105, 69, 62, 48, and $9 \mathrm{~kb})$, MAFF302683 (103, 68, $61,48,12$, and $9 \mathrm{~kb})$, MAFF302694 (102, 72, 60, 46, 9, and $6 \mathrm{~kb})$, and MAFF302754 (102, 89, 75, 60, 51, 15, and $12 \mathrm{~kb}$ ) (Fig. 1A). Plasmid DNA was then transferred to nylon membranes and used for Southern hybridization experiments to detect plasmids that carry efe. The efe probe hybridized to a $93-\mathrm{kb}$ plasmid band in pv. glycinea MAFF301683 and to a 102- to 105-kb plasmid band in other strains. It also hybridized weakly to a 59-kb plasmid band in pv. glycinea; but this is thought to be a nonspecific reaction. On the other hand, the $c f l$ probe hybridized to both the $93-\mathrm{kb}$ and $102-$ to $105-\mathrm{kb}$ plasmid bands, suggesting that 93-kb and 102- to 105-kb plasmids in these strains may carry both efe and $\mathrm{cfl}$. In contrast, both probes failed to hybridize with other plasmids ranging from 6 to $89 \mathrm{~kb}$ in pv. glycinea (Fig. 1B and C) and with plasmids in pv. mori S6801 and pv. tabaci BR2 (RSF1010) (data not shown).

Transposon mutagenesis and PCR. Strain 301683-r was mated with $E$. coli $\mathrm{S} 17$ ( $\lambda$ pir) harboring pUT::mini-Tn5-Km1. Many transposon-insertion mutants were obtained in the mating, and $38 \mathrm{mu}-$ tants were screened by Southern blot hybridization for transposon insertions into indigenous plasmids. Among them, four mutants (designated P1, P2, P3, and P5) harbored a plasmid shown to contain mini-Tn5-Km1 (Fig. 2). Southern blot analysis using the $\mathrm{Tn} 5-\mathrm{Km} 1$ ribo-probe revealed that mini- $\mathrm{Tn} 5-\mathrm{Km} 1$ was inserted into the largest plasmid $(93 \mathrm{~kb})$ in $\mathrm{P} 2$ and $\mathrm{P} 3$, but into smaller plasmids in P1 and P5 (Fig. 2).

To separate the $93-\mathrm{kb}$ plasmid from the other indigenous plasmids of MAFF301683, P2 and P3 (93-kb plasmid::mini-Tn5-Km1) were mated separately with $P$. syringae $\mathrm{Ni} 27^{\mathrm{n}}$ on membranes. To select the transconjugants, modified LB medium containing $20 \mu \mathrm{g}$ of nalidixic acid per $\mathrm{ml}$ and $20 \mu \mathrm{g}$ of kanamycin per $\mathrm{ml}$ was used. $\mathrm{P} 2$ and $\mathrm{P} 3$ transconjugants were obtained at a frequency of $1.3 \times 10^{-8}$ and $5.0 \times 10^{-8}$ per recipient, respectively, in these matings. These transconjugants were designated C2-1, C2-2, and C2-3 (obtained from mating with P2) and C3-1, C3-2, and C3-3 (obtained from mating with P3). A 93-kb plasmid was detected in all the $\mathrm{C} 2$ (Fig. 3A, lanes b, c, and d) and C3 (Fig. 3A, lanes f, g, and h) transconjugants. Next, plasmids from the $\mathrm{C} 2$ and $\mathrm{C} 3$ derivatives were hybridized with efe and $c f l$ probes in Southern blots. The efe probe hybridized to the plasmid in the $\mathrm{C} 2$ derivatives, but not to the one in the $\mathrm{C} 3$ derivatives (Fig. 3B). In contrast, the $c f l$ probe hybridized to the plasmid in the $\mathrm{C} 3$ derivatives, but not to the one in the

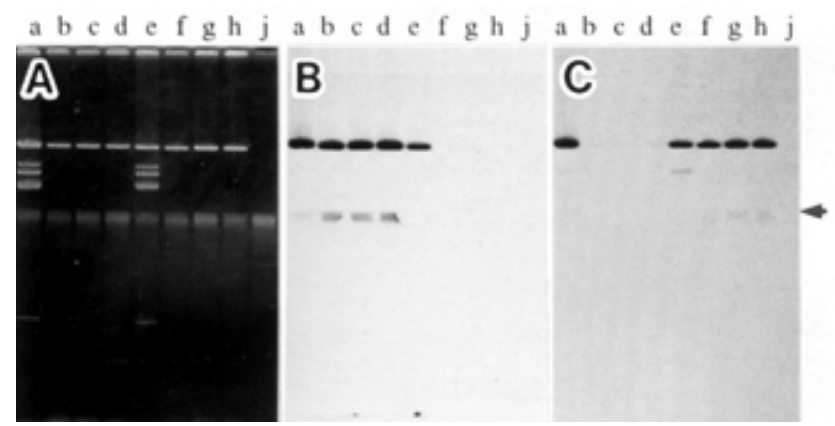

Fig. 3. Plasmid profiles of A, Pseudomonas syringae $\mathrm{Ni} 27^{\mathrm{n}}$ strains that acquired pETH2 or pCOR2 and Southern blot hybridization to the plasmids probed with $\mathbf{B}$, the efe gene or $\mathbf{C}$, the $c f l$ gene. Lane a, 301683-r::mini-Tn5$\mathrm{P} 2$; b, c, and d, Ni27 $7^{\mathrm{n}}(\mathrm{pETH} 2)$ transconjugants designated as $\mathrm{C} 2-1, \mathrm{C} 2-2$, and C2-3, respectively; e, 301683-r::mini-Tn5-P3; f, g, and h, Ni27n (pCOR2) transconjugants designated as $\mathrm{C} 3-1, \mathrm{C} 3-2$, and $\mathrm{C} 3-3$, respectively; and $\mathrm{j}$, $\mathrm{Ni} 27^{\mathrm{n}}$. An arrow shows the linear chromosomal DNA band.
C2 derivatives (Fig. 3C). These results revealed that the 93-kb plasmid band of MAFF301683 was composed of two different similar size plasmids.

Likewise, a PCR assay using primers ETH1-ETH2 to amplify efe produced a product only with the $\mathrm{C} 2$ derivatives, whereas PCR using primers Cor1-Cor2 to amplify $c f l$ was positive only for the C3 derivatives (Fig. 4). The BamHI restriction patterns of the plasmids in $\mathrm{C} 2$ and $\mathrm{C} 3$ transconjugants were different (data not shown). Therefore, we designated the plasmid from the $\mathrm{C} 2$ derivatives as pETH2 (ethylene plasmid) and the plasmid from $\mathrm{C} 3$ derivatives as pCOR2 (coronatine plasmid).

Ethylene and coronatine production. Eight strains including P2, P3, C2 derivatives, C3 derivatives, MAFF301683, and Ni27 ${ }^{\mathrm{n}}$ were examined for their ethylene-producing ability by GC analysis. As shown in Table 2, Ni27 ${ }^{\mathrm{n}}$ (pETH2) (the $\mathrm{C} 2$ derivatives), and wild-type strain MAFF301683 and its derivatives (P2, P3) produced ethylene efficiently, whereas $\mathrm{Ni} 27^{\mathrm{n}}$, with and without pCOR2, did not. The amount of ethylene produced by MAFF301683 was 2,055 $\mathrm{nl}$ per $\mathrm{mg}$ of cells per h. Likewise, a similar high level of ethylene production was detected in $\mathrm{Ni} 27^{\mathrm{n}}$ transconjugants harboring $\mathrm{pETH} 2$, but not pCOR2, indicating that efe was adequately expressed in a different pathovar of $P$. syringae. On the other hand, coronatine production was only observed in the transconjugants that had acquired pCOR2, but not pETH2. Thus, the production of ethylene or coronatine in a nonproducing strain of $P$. syringae (unknown pathovar) was verified for transconjugants that had acquired $\mathrm{pETH} 2$ or $\mathrm{pCOR} 2$, respectively.

\section{DISCUSSION}

In microorganisms, two pathways for ethylene production have been reported. One pathway synthesizes ethylene via 2-oxoglutarate using an ethylene-forming enzyme $(e f e)(9,10)$ and the other pathway makes it via 2-keto-4-methyl-thiobutyric acid using an NADH: Fe(III)EDTA oxidoreductase (13). Only four pathovars of $P$. syrin-

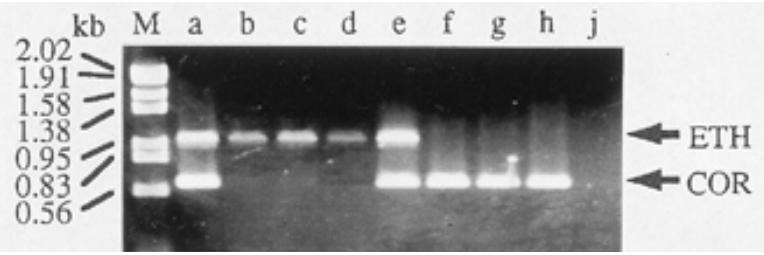

Fig. 4. Polymerase chain reaction (PCR) amplification of efe or $c f l$ from Pseudomonas syringae pv. glycinea MAFF301683 and P. syringae $\mathrm{Ni27}{ }^{\mathrm{n}}$ (pETH2) or $\mathrm{Ni}^{2} 7^{\mathrm{n}}$ (pCOR2) transconjugants. Lane $\mathrm{M}$, molecular size markers $\left(\lambda /\right.$ HindIII/EcoRI); a, 301683-r::mini-Tn5-P2; b, c, and d, Ni27 ${ }^{\text {n}}$ (pETH2) transconjugants designated as $\mathrm{C} 2-1, \mathrm{C} 2-2$, and $\mathrm{C} 2-3$, respectively; e, 301683-r::mini-Tn5-P3; f, g, and h, Ni27n (pCOR2) transconjugants designated as $\mathrm{C} 3-1, \mathrm{C} 3-2$, and $\mathrm{C} 3-3$, respectively; and $\mathrm{j}, \mathrm{Ni27^{ \textrm {n } }}$. Arrows show PCR products amplified by primers ETH1-ETH2 (ETH) or primers Cor1-Cor2 (COR).

TABLE 2. Production of ethylene and coronatine by Pseudomonas syringae $\mathrm{Ni} 27^{\mathrm{n}}$ transconjugants that acquired $\mathrm{pETH} 2$ or pCOR 2 plasmids by mating with MAFF301683-r::mini-Tn5

\begin{tabular}{|c|c|c|}
\hline Strains (plasmid) & $\begin{array}{l}\text { Ethylene production }{ }^{\mathrm{a}} \\
\text { (nl/mg cells/h) }\end{array}$ & $\begin{array}{l}\text { Coronatine } \\
\text { production }^{\mathrm{b}}\end{array}$ \\
\hline 301683-r::mini-Tn5-P2 & 1,715 & + \\
\hline $\mathrm{Ni}_{27}^{\mathrm{n}}(\mathrm{pETH} 2) \mathrm{C} 2-1$ & 1,507 & - \\
\hline $\mathrm{Ni27}{ }^{\mathrm{n}}(\mathrm{pETH} 2) \mathrm{C} 2-2$ & 1,002 & - \\
\hline 301683-r::mini-Tn5-P3 & 1,502 & + \\
\hline $\mathrm{Ni}_{2}{ }^{\mathrm{n}}(\mathrm{pCOR} 2) \mathrm{C} 3-1$ & 0 & + \\
\hline $\mathrm{Ni}^{2} 7^{\mathrm{n}}(\mathrm{pCOR} 2) \mathrm{C} 3-2$ & 0 & + \\
\hline MAFF301683 wild type & 2,055 & + \\
\hline $\mathrm{Ni} 27^{\mathrm{n}}$ & 0 & - \\
\hline
\end{tabular}

a The values represent means obtained from three independent experiments.

$\mathrm{b}$ The potato assay of Nishiyama (12) was used. 
gae including pv. glycinea have been found to possess efe (21) and use the former pathway. In the current study, the plasmid location of efe in pv. glycinea MAFF301683 was verified. This is the first proof of plasmid-borne ethylene production in microorganisms, although this possibility was previously suggested by Nagahama et al. (11) and Sato et al. (21). Our findings further suggest that the 102 - to $105-\mathrm{kb}$ plasmids in four other strains of pv. glycinea used in this study are also ethylene plasmids. Likewise, several plasmids from pv. cannabina and kudzu strains of pv. phaseolicola, which hybridized to the efe probe, are likely to contain efe (21).

The pETH2 plasmid was transmissible from $P$. syringae pv. glycinea to $P$. syringae, and the transconjugants were able to efficiently produce ethylene. Strain $\mathrm{Ni} 27^{\mathrm{n}}$, which was isolated from mulberry leaves, is only very weakly pathogenic (or nonpathogenic) to mulberry and can be easily distinguished from strains of pv. mori and the "pv. glycinea and pv. phaseolicola" group by PCR restriction fragment length polymorphism (RFLP) analysis of hrp genes (K. Watanabe, K. Nishiyama, and M. Sato, unpublished data). Therefore, $\mathrm{Ni} 27^{\mathrm{n}}$ is currently considered to be an unidentified pathovar, and it is different from pv. glycinea based on the above-mentioned PCR-RFLP and its inability to produce coronatine and ethylene. The finding of in vitro transfer of an ethylene plasmid to another pathovar of $P$. syringae suggests that similar conjugal transfer of $e f e$ can occur among pathovars of $P$. syringae in nature.

The transfer frequency of pETH2 to Ni27 was very low, only $1.3 \times 10^{-8}$ per recipient. In a previous report, the transfer frequency of pBPW1 (an indigenous plasmid of $P$. syringae pv. tabaci BR2) to the same recipient strain (Ni27-Rif) was $1.0 \times 10^{0}(16)$. Unlike pBPW1, which is naturally derepressed for transfer, pETH2 appears to have repressed fertility functions. It is also possible that $\mathrm{pETH} 2$ could be mobilized by other indigenous plasmids of MAFF301683 (Fig. 1). The low frequency of transfer of pETH2 suggests that horizontal dispersion among bacteria by conjugation does not occur frequently in nature, although some factors that enhance plasmid transfer may exist.

Interestingly, the molecular size of $\mathrm{pETH} 2$ was similar to that of pCOR2. However, these plasmids could be distinguished from each other by endonuclease cleavage patterns (data not shown). In other strains of pv. glycinea, probes of both efe and cfl genes hybridized to the largest plasmid(s), which were similar in size (102 to $105 \mathrm{~kb}$ ). To determine whether or not these genes reside on the same plasmid in each strain, more studies will be required. Several sizes of plasmids encoding coronatine biosynthesis genes (Cor-genes) have been detected in the $P$. syringae pathovars atropurpurea (17), tomato (1), glycinea (25), and maculicola (26). Among them, at least two plasmids, pCOR1 of pv. atropurpurea and pPT23A of pv. tomato, were conjugative $(1,15)$. In this study, pCOR2 was also shown to be conjugative. Comparative studies between these coronatine plasmids would be valuable in understanding the evolution of Cor-genes in $P$. syringae.

Weingart and Völksch (24) have recently reported that pv. glycinea produces ethylene in planta, suggesting a potential role for ethylene in pathogenicity. Coronatine has been found to be associated with the development of some symptoms of pv. glycinea infection (6). All strains of pv. glycinea produce ethylene $(20,22)$ and most strains produce coronatine (22, this study). These findings suggest that both phenotypes are advantageous for the survival of pv. glycinea in soybeans. $\mathrm{Ni} 27^{\mathrm{n}}$ strains harboring both plasmids obtained in this study could be used for studying the role of efe and Cor-genes in pathogenicity or survival. In this study, it was found that most strains of pv. glycinea harbor both the ethylene plasmid and the coronatine plasmid. No other plantpathogenic bacteria harboring two plasmids encoding efe and Cor-genes are known. These findings are important from the viewpoint of the evolution of pv. glycinea. For example, we can speculate that an ethylene plasmid first may have been intro- duced into pro-pv. glycinea, followed by a coronatine plasmid, to create pv. glycinea.

\section{ACKNOWLEDGMENTS}

This work was supported by a Grant-in-Aid from the Ministry of Agriculture, Forestry and Fisheries, Japan. We thank K. Nishiyama and the Ministry of Agriculture, Forestry and Fisheries, Japan (MAFF) for supplying bacterial stains.

\section{LITERATURE CITED}

1. Bender, C. L., Malvick, D. K., and Mitchell, R. E. 1989. Plasmid-mediated production of the phytotoxin coronatine in Pseudomonas syringae pv. tomato. J. Bacteriol. 171:807-812.

2. Bereswill, S., Bugert, P., Völksch, B., Ullrich, M., Bender, C. L., and Geider, K. 1994. Identification and relatedness of coronatine-producing Pseudomonas syringae pathovars by PCR analysis and sequence determination of the amplification products. Appl. Environ. Microbiol. 60:2924-2930.

3. Birnboim, H. C., and Doly, J. 1979. A rapid alkaline extraction procedure for screening recombinant plasmid DNA. Nucleic Acids Res. 7: 1513-1523.

4. Freebairn, H. T., and Buddendenhagen, I. W. 1964. Ethylene production by Pseudomonas solanacearum. Nature 202:313-314.

5. Fukuda, H., Ogawa, T., Ishihara, K., Fujii, T., Nagahama, K., Omata, T., Inoue, Y., Tanase, S., and Morino, Y. 1992. Molecular cloning in Escherichia coli, expression and nucleotide sequence of the gene for the ethylene-forming enzyme of Pseudomonas syringae pv. phaseolicola PK2. Biochem. Biophys. Res. Commun. 188:826-832.

6. Gnanamanickam, S. S., Starratt, A. N., and Ward, E. M. B. 1982. Coronatine production in vitro and in vivo and its relation to symptom development in bacterial blight of soybean. Can. J. Bot. 60:645-650.

7. Goto, M., Ishida, Y., Takikawa, Y., and Hyodo, H. 1985. Ethylene production by kudzu strains of Pseudomonas syringae pv. phaseolicola causing halo blight in Pueraria lobata (Willd.) Ohwi. Plant Cell Physiol. 26:141-150.

8. Lorenzo, V., Herrero, M., Jakubzik, U., and Timmis, K. N. 1990. Mini$\mathrm{Tn} 5$ transposon derivatives for insertion mutagenesis, promoter probing, and chromosomal insertion of cloned DNA in Gram-negative eubacteria. J. Bacteriol. 172:6568-6572.

9. Nagahama, K., Ogawa, T., Fujii, T., Tazaki, M., Goto, M., and Fukuda, H. 1991. L-Arginine is essential for the formation in vitro of ethylene by an extract of Pseudomonas syringae. J. Gen. Microbiol. 137: 1641-1646.

10. Nagahama, K., Ogawa, T., Fujii, T., Tazaki, M., Tanase, S., Morino, Y., and Fukuda, H. 1991. Purification and properties of an ethyleneforming enzyme from Pseudomonas syringae. J. Gen. Microbiol. 137: 2281-2286

11. Nagahama, K., Yoshino, K., Matsuoka, M., Sato, M., Tanase, S., Ogawa, T., and Fukuda, H. 1994. Ethylene production by strains of the plantpathogenic bacterium Pseudomonas syringae depends upon the presence of indigenous plasmids carrying homologous genes for the ethyleneforming enzyme. Microbiology 140:2309-2313.

12. Nishiyama, K. 1981. Studies on the pathogenicity-related substances in Pseudomonas coronafaciens var. atropurpurea. Bull. Natl. Inst. Agric. Sci. C 35:1-15.

13. Ogawa, T., Takahashi, M., Fujii, T., Tazaki, M., and Fukuda, H. 1990. The role of NADH:Fe(III)EDTA oxidoreductase in ethylene formation from 2-keto-4-methylthiobutrate. J. Ferment. Bioeng. 69:287-291.

14. Sambrook, J., Fritsch, E. F., and Maniatis, T. 1982. Plasmid vectors. Pages 1.1-1.110 in: Molecular Cloning: A Laboratory Manual. 2nd ed. Cold Spring Harbor Laboratory Press, Cold Spring Harbor, NY.

15. Sato, M. 1988. In planta transfer of the genes for virulence between isolates of Pseudomonas syringae pv. atropurpurea. Ann. Phytopathol. Soc. Jpn. 54:20-24.

16. Sato, M., Nishiyama, K., and Panopoulos, N. J. 1985. Conjugative transmission and replicative properties of plasmid pBPW1, and antigen alteration induced by the plasmid in pathovars of Pseudomonas syringae. Ann. Phytopathol. Soc. Jpn. 51:426-434.

17. Sato, M., Nishiyama, K., and Shirata, A. 1983. Involvement of plasmid DNA in the production of coronatine by Pseudomonas syringae pv. atropurpurea. Ann. Phytopathol. Soc. Jpn. 49:522-528.

18. Sato, M., Staskawicz, B. J., and Panopoulos, N. J. 1982. Indigenous plasmids of Pseudomonas syringae pv. mori, the causal agent of bacterial blight of mulberry. Ann. Phytopathol. Soc. Jpn. 48:27-33.

19. Sato, M., Staskawicz, B. J., Panopoulos, N. J., Peters, S., and Homma, M. 1981. A host-dependent hybrid plasmid suitable as a suicidal carrier for transposable elements. Plasmid 6:325-331. 
20. Sato, M., Urushizaki, K., Nishiyama, K., Sakai, F., and Ota, Y. 1987. Efficient production of ethylene by Pseudomonas syringae pv. glycinea which causes halo blight in soybeans. Agric. Biol. Chem. 51: 1177-1178.

21. Sato, M., Watanabe, K., Yazawa, M., Takikawa, Y., and Nishiyama, K. 1997. Detection of new ethylene-producing bacteria, Pseudomonas syringae pvs. cannabina and sesami, by PCR amplification of genes for the ethylene-forming enzyme. Phytopathology 87:1192-1196.

22. Völksch, B., and Weingart, H. 1997. Comparison of ethylene producing Pseudomonas syringae strains isolated from kudzu (Pueraria lobata) with Pseudomonas syringae pv. phaseolicola and Pseudomonas syringae pv. glycinea. Eur. J. Plant Pathol. 103:795-802.

23. Watanabe, K., Katsuhara, M., Nakao, H., and Sato, M. 1997. Detection and molecular analysis of plant- and insect-associated bacteria harboring aconitate isomerase involved in biosynthesis of trans-aconitic acid as antifeedant in brown planthoppers. Curr. Microbiol. 35:97-102.

24. Weingart, H., and Völksch, B. 1997. Ethylene production by Pseudomonas syringae pathovars in vitro and in planta. Appl. Environ. Microbiol. 63:156-161.

25. Young, S. A., Park, S. K., Rodgers, C., Mitchell, R. E., and Bender, C. L. 1992. Physical and functional characterization of the gene cluster encoding the polypeptide phytotoxin coronatine in Pseudomonas syringae pv. glycinea. J. Bacteriol. 174:1837-1843.

26. Zhu, Y., Tamura, K., Watanabe, M., Matsuda, I., and Sato, M. 1995. Plasmid-mediated coronatine production in Pseudomonas syringae pv. maculicola. Ann. Phytopathol. Soc. Jpn. 61:569-574. 